Jurnal Indonesia Sosial Teknologi:p-ISSN: 2723 - 6609

e-ISSN :2745-5254

Vol. 2, No.12 Desember 2021

\title{
PENGEMBANGAN MODEL KRITERIA BAURAN PEMASARAN ONLINE PADA TAHAP CREATIVITY \& DIRECTION MENGGUNAKAN FUZZY AHP (STUDI KASUS: INDUSTRI KREATIF DI INDONESIA)
}

\author{
Hasrini Sari $^{1}$, Made Andriani ${ }^{2}$, Irfan Rusydi Triyanto ${ }^{3}$ \\ Jurusan Teknik Manajemen Industri, Fakultas Teknologi Industri, Institut Teknologi \\ Bandung \\ Email: hasrinis@gmail.com ${ }^{1}$, mdandriani@gmail.com ${ }^{2}$ irfan.rusydi.t@gmail.com, ${ }^{3}$
}

\begin{abstract}
Abstrak
Internet berkembang dengan pesat di Indonesia. Perkembangan internet membantu berbagai sektor untuk tumbuh, salah satunya UMKM sebagai salah satu tulang punggung perekonomian Indonesia. Pemanfaatan internet pada UMKM mendorong pemanfaatan pemasaran online. Pemasaran online memberi keuntungan dan kemudahan yang tidak ada pada pemasaran offline. Penggunaan pemasaran online perlu disesuaikan dengan kemampuan dan kebutuhan perusahaan agar pemasaran online yang dilakukan dapat berjalan secara efektif dan efisien. Di Indonesia, pemanfaatan internet pada UMKM cukup rendah disebabkan oleh pengetahuan pelaku usaha yang belum mampu menggunakan internet dalam pertumbuhan UMKM. Pemasaran juga menjadi masalah bagi UMKM dimana 74\% UMKM mengalami kesulitan pada akses pemasaran. Masalah tersebut akan menghambat pertumbuhan UMKM. Penelitian ini bertujuan merancang model bauran pemasaran online yang ditujukan pada UMKM dan juga membuat prioritas bauran pemasaran kedalam dua tahap pertumbuhan organisasi, yaitu tahap creativity dan tahap direction. Penelitian dilakukan terhadap 6 partisipan UMKM yang berada pada tahap creativity dan tahap direction melalui wawancara terstruktur untuk mengetahui kriteria bauran pemasaran online dan dilanjutkan dengan penggunaan metode fuzzy AHP dalam menentukan peringkat kriteria. Kesimpulan dari penelitian adalah ditemukan 40 kriteria penting bauran pemasaran online yang terdiri dari 10 kriteria pada dimensi produk, 8 kriteria pada dimensi harga, 10 kriteria pada dimensi tempat dan 12 kriteria pada dimensi promosi. Perbedaan posisi kriteria bauran pemasaran terdapat pada tahap pertumbuhan creativity dan tahap direction.
\end{abstract}

Kata kunci: Bauran pemasaran online, creativity, direction, fuzzy AHP, UMKM

\section{Abstract}

Internet is growing rapidly in Indonesia. The development of the internet helps various sectors to grow, one of which is MSMEs as one of the backbones of the Indonesian economy. The use of the internet in MSMEs encourages the use ofmarketing online. Marketing Online provides advantages and conveniences that are not present inmarketing offline. The use ofmarketing online needs to be adjusted to the capabilities and needs of the company so thatmarketing online can run effectively and efficiently. In Indonesia, the use of the internet in MSMEs is quite low due to the knowledge of business actors who have not been able to use the internet 
Pengembangan Model Kriteria Bauran Pemasaran Online Pada Tahap Creativity \& Direction Menggunakan Fuzzy Ahp (Studi Kasus: Industri Kreatif Di Indonesia)

in the growth of MSMEs. Marketing is also a problem for MSMEs where 74\% of MSMEs have difficulty accessing marketing. This problem will hamper the growth of MSMEs. This study aims to design anmarketing mix model online aimed at MSMEs and also to prioritize the marketing mix into two stages of organizational growth, namely the creativity stage and thestage direction. The study was conducted on 6 MSME participants who were in thestage creativity and thestage direction through structured interviews to determine the criteria for themarketing mix online and continued with the use of themethod fuzzy AHPin determining the ranking criteria. The conclusion of the research is that 40 important criteria for themarketing mix were found online, consisting of 10 criteria on the product dimension, 8 criteria on the price dimension, 10 criteria on the place dimension and 12 criteria on the promotion dimension. The difference in the position of the marketing mix criteria is in thegrowth creativity stage and thestage direction.

Keywords: Online marketing mix, creativity, direction, fuzzy AHP, UMKM

\section{Pendahuluan}

Kemajuan di bidang teknologi dan komunikasi mendorong adanya perkembangan internet. Perkembangan internet memudahkan pelaku bisnis dalam memperoleh informasi untuk menjalankan aktivitas bisnisnya (Widyastuti, 2020). Pertumbuhan pengguna internet di Indonesia mendorong potensi pengguna internet dapat dimanfaatkan oleh beberapa pihak, salah satunya oleh UMKM (Usaha Mikro Kecil Menengah). Jumlah UMKM di Indonesia adalah 97\% dari keseluruhan Badan Usaha yang terdapat di Indonesia. Di Indonesia, Undang-Undang yang mengatur tentang Usaha Mikro, Kecil, dan Menengah (UMKM) adalah Undang-Undang Nomor 20 Tahun 2008. UndangUndang tersebut mendefinisikan UMKM sebagai usaha ekonomi produktif yang berdiri sendiri, dilakukan oleh perorangan atau badan usaha yang bukan merupakan anak perusahaan sesuai dengan kriteria yang diatur oleh pemerintah dalam Undang-Undang dan melakukan kegiatan ekonomi atau berdomisili di Indonesia (Indonesia, 2008). UMKM dibagi menjadi 3 jenis usaha, yaitu usaha mikro, usaha kecil, dan usaha menengah.

UMKM terdiri dari beberapa sektor, salah satunya industri kreatif. Industri kreatif merupakan industri yang berasal dari pemanfaatan kreativitas, keterampilan \& bakat individu untuk menciptakan lapangan pekerjaan (Kemendag, 2008). Menurut Restog K. Kusuma, Direktur Akses Perbankan Bekraf, dari 18 subsektor industri kreatif, kontribusi terbesar didominasi oleh 3 sektor, diantaranya fashion, kuliner, \& kerajinan (Bisnis.com). Pertumbuhan UMKM bukan berarti tanpa masalah. Menurutnya ketiga sektor tersebut belum memanfaatkan pemasaran secara optimal. Dikutip dari berita Gatra pada tahun 2018, Hemas menjelaskan jumlah UMKM yang bertambah diiringi dengan 74\% diantaranya mengalami kesulitan pada pemasaran (Gatra, 2018). Permasalahan yang dialami oleh UMKM membuat peneliti melakukan penelitian terkait pemasaran. Tema yang sering dibahas adalah bauran pemasaran.

Definisi pemasaran menurut American Marketing Association dalam (Kotler \&

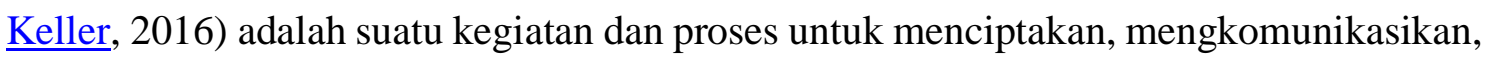


menyampaikan, dan memberikan penawaran yang bernilai bagi pelanggan, klien, mitra, dan masyarakat luas. Bauran Pemasaran adalah kumpulan dari perangkat pemasaran (produk, harga, tempat, promosi) yang dipadukan oleh perusahaan agar mendapat respon dari pasar yang dituju (Kotler, 2012). Pemasaran UMKM mungkin dapat didukung dengan penggunaan internet. Penggunaan internet pada UMKM dapat mengurangi biaya pengeluaran (Nezamabad, 2011). Internet Marketing juga merupakan aplikasi dari internet dan teknologi-teknologi digital terkait untuk mencapai tujuan-tujuan pemasaran, teknologi-teknologi itu seperti media internet, kabel kabel, satelit, perangkat keras, perangkat lunak yang diperlukan untuk keperluan Internet Marketing tersebut (Chaffey, Ellis-Chadwick, Mayer, \& Johnston, 2009). Social Media Marketing merupakan salah satu bentuk dari Internet Marketing adalah dengan menggunakan. Media sosial didefinisikan sebagai aplikasi online atau media yang digunakan untuk melakukan interaksi, kerjasama atau penyebaran konten diantara penggunanya (Richter \& Koch, 2007).

Penggunaan media sosial pada sektor industri kreatif telah dimanfaatkan dengan cukup baik, dimana 53\% pelakunya memanfaatkan media sosial sebagai sarana promosi (Nuriyanti, 2019). Potensi penggunaan media sosial sebagai sarana promosi produk didukung oleh 150 juta pengguna media sosial aktif di Indonesia pada tahun 2018 (Hootsuite). Penggunaan media sosial di Indonesia memiliki potensi yang besar, namun belum dapat dimanfaatkan secara utuh oleh pemasar. Berdasarkan pengamatan pada tahun 2017, 55\% pemasar belum mampu meningkatkan potensi dari pemasaran online (Marketeers, 2017). Permasalahan lain yang dihadapi pada Bauran Pemasaran sebuah UMKM yaitu budget, staf, dan metode komunikasi yang berbeda dibandingkan oleh perusahaan besar (Schenck, 2012). Menurut (Gilmore, Carson, \& Grant, 2001) perbedaan pemasaran dari UMKM \& perusahaan besar tidak hanya berdasarkan terbatasnya sumber daya yang dimiliki UMKM, namun perbedaan dari cara berpikir dan tindakan yang dilakukan oleh pemilik usaha. Perlu adanya pendekatan alternatif dalam menggunakan bauran pemasaran yang dijalankan oleh UMKM (Gilmore et al., 2001). Berdasarkan pertimbangan tersebut, dibutuhkan penelitian terhadap bauran pemasaran yang mempertimbangkan aspek pertumbuhan organisasi.

Peneliti tahap pertumbuhan organisasi yang cukup dikenal adalah (Greiner, 1972). Tahap pertumbuhan organisasi yang dikeluarkan oleh (Greiner, 1972) diadaptasi oleh proses pertumbuhan makhluk hidup. Namun tahap pertumbuhan dari penelitian (Greiner, 1972) tidak secara khusus terkait UMKM. Penelitian (Albuquerque, Escrivão Filho, Nagano, \& Junior, 2016) menjelaskan 2 tahap awal pertumbuhan organisasi optimal digunakan pada penelitian pertumbuhan organisasi pada UMKM, disebabkan banyak UMKM pada tahap tersebut mengalami kebangkrutan. Kedua tahap pertumbuhan organisasi pada penelitian Larry Greiner adalah tahap creativity \& Direction (Albuquerque et al., 2016). Penelitian difokuskan pada kedua tahap pertumbuhan organisasi tersebut 
Pengembangan Model Kriteria Bauran Pemasaran Online Pada Tahap Creativity \& Direction Menggunakan Fuzzy Ahp (Studi Kasus: Industri Kreatif Di Indonesia)

\section{Metode Penelitian}

Metode penelitian yang digunakan dalam penelitian ini adalah metode penelitian kualitatif dan metode penelitian kuantitatif. Menurut (Sugiyono, 2017) "Metode penelitian kualitatif sering disebut metode penelitian naturalistik karena penelitiannya dilakukan pada kondisi yang alamiah (natural setting); disebut juga sebagai metode etnografi, karena pada awalnya metode ini lebih banyak digunakan untuk penelitian bidang antropologi budaya; disebut sebagai metode kualitatif, karena data yang terkumpul dan analisisnya lebih bersifat kualitatif.

Metode pengambilan data dimulai dari wawancara, dimana partisipan di wawancara terkait bauran pemasaran 4P (price, place, promotion, product) dan menjelaskan usaha untuk mengetahui tingkat dari organisasinya. Teknik pemilihan sampel menggunakan purposive sampling. Purposive sampling adalah teknik pengambilan sampel sumber data dengan pertimbangan tertentu (Sugiyono, 2012). Penggunaan teknik tersebut didasari oleh pemahaman partisipan terhadap bidang yang ditekuninya, yaitu partisipan merupakan orang yang memahami tentang bidang usaha yang ditekuninya. Partisipan yang ikut pada penelitian ini merupakan pemilik usaha di daerah kota Bandung dan sekitarnya. Jumlah partisipan dapat dilihat pada Tabel 4.

Tabel 4. Partisipan Penelitian

\begin{tabular}{|c|c|c|c|c|c|c|}
\hline No & $\begin{array}{l}\text { Nama } \\
\text { Partisipan }\end{array}$ & $\begin{array}{l}\text { Nama Usaha } \\
\text { / Jenis Bisnis }\end{array}$ & $\begin{array}{l}\text { Tahun } \\
\text { berdiri }\end{array}$ & $\begin{array}{l}\text { Sektor } \\
\text { Industri }\end{array}$ & $\begin{array}{l}\text { Tanggal } \\
\text { dan Waktu } \\
\text { Wawancara }\end{array}$ & $\begin{array}{l}\text { Tempat } \\
\text { Wawancara }\end{array}$ \\
\hline 1 & $\begin{array}{l}\text { Pak Tata } \\
\text { Santa } \\
\text { (pemilik) } \\
\& \quad \text { Kang } \\
\text { Ugi } \\
\text { (karyawan) }\end{array}$ & $\begin{array}{l}\text { Kicimpring } \\
\text { Cidadap / } \\
\text { Kicimpring }\end{array}$ & 2018 & Makanan & $\begin{array}{l}19 \\
\text { November } \\
2019-16.00\end{array}$ & Rumah \\
\hline 2 & $\begin{array}{l}\mathrm{Bu} \text { Indah } \\
\text { (pemilik) }\end{array}$ & $\begin{array}{l}\text { Qaireenmoez/ } \\
\text { baju } \\
\text { Wastra }\end{array}$ & 2014 & Fashion & $\begin{array}{l}20 \\
\text { november } \\
2019 \\
-15.00\end{array}$ & Rumah \\
\hline 3 & $\begin{array}{l}\mathrm{Bu} \text { Yemi } \\
\text { Sudibyo } \\
\text { (pemilik) }\end{array}$ & $\begin{array}{l}\text { YME Gallery } \\
\& \text { Yemi } \\
\text { Sudibjo/ baju } \\
\text { muslim }\end{array}$ & 2011 & Fashion & $\begin{array}{l}5 \text { Desember } \\
2019 \\
-14.00\end{array}$ & Rumah \\
\hline 4 & $\begin{array}{l}\mathrm{Bu} \text { Aneu } \\
\text { (pemilik) }\end{array}$ & $\begin{array}{l}\text { Sharena } \\
\text { Handicraft / } \\
\text { handicraft }\end{array}$ & 2016 & Kerajinan & $\begin{array}{l}01 \text { Februari } \\
2020-14.00\end{array}$ & Toko \\
\hline 5 & $\begin{array}{l}\text { Bu Titah } \\
\text { (pemilik) }\end{array}$ & $\begin{array}{l}\text { Mama masak } \\
\text { / sambal }\end{array}$ & 2019 & Makanan & $\begin{array}{l}03 \text { Februari } \\
2020-14.00\end{array}$ & Cafe \\
\hline
\end{tabular}




\begin{tabular}{lllllll}
\hline No & $\begin{array}{l}\text { Nama } \\
\text { Partisipan }\end{array}$ & $\begin{array}{l}\text { Nama Usaha } \\
\text { / Jenis Bisnis }\end{array}$ & $\begin{array}{l}\text { Tahun } \\
\text { berdiri }\end{array}$ & $\begin{array}{l}\text { Sektor } \\
\text { Industri }\end{array}$ & $\begin{array}{l}\text { Tanggal } \\
\text { dan Waktu } \\
\text { Wawancara }\end{array}$ & $\begin{array}{l}\text { Tempat } \\
\text { Wawancara }\end{array}$ \\
\hline 6 & $\begin{array}{lllllll}\text { Bu Yayah } \\
\text { (pemilik) }\end{array}$ & $\begin{array}{l}\text { Ranemo } \\
\text { (Rajutan }\end{array}$ & 2016 & Kerajinan & 07 Februari & Toko \\
& & Nenek & & & $2020-16.30$ & \\
& & & & & \\
& & & & & \\
& & & & & & \\
\hline
\end{tabular}

Penelitian kualitatif dengan melakukan reduksi data. Setelah melalui proses reduksi data, dilanjutkan dengan triangulasi. Triangulasi digunakan sebagai teknik untuk mengecek keabsahan data. Dimana dalam pengertiannya triangulasi adalah teknik pemeriksaan keabsahan data yang memanfaatkan sesuatu yang lain dalam membandingkan hasil wawancara terhadap objek penelitian (Moleong, 2012). Teknik analisis kualitatif yang dilakukan pada penlitian ini menggunakan first cycling codes dan second cycling codes. Metode ini ditemukan oleh (Miles, Huberman, \& Saldana, 2014) pada bukunya yang berjudul "Qualitative Data Analysis: A Method Sourcebook".

First cycling codes berperan melakukan proses dari sebuah coding yang terdiri dari kata hingga paragraf. Terdapat tiga metode yang berfungsi sebagai fondasi utama untuk pengodean (Miles et al., 2014) antara lain descriptive coding, in vivo coding dan process coding. Penelitian ini menggunakan in vivo coding. In vivo coding menggunakan kata-kata atau frasa singkat dari bahasa partisipan sendiri dalam catatan data. In vivo coding sesuai untuk hampir semua studi kualitatif terutama bagi peneliti kualitatif bagaimana memberi kode pada data yang sifatnya memprioritaskan dan mempertimbangkan pendapat partisipan. Second cycle coding atau pattern codes menurut (Miles et al., 2014) merupakan pengelompokan hasil kesimpulan yang dilakukan akan dikelompokkan dalam bentuk tema, kategori maupun theoretical construct.

Metode penelitian kuantitatif menggunakan Fuzzy AHP. Fuzzy AHP merupakan Fuzzy AHP merupakan gabungan metode AHP dengan pendekatan konsep Fuzzy (Raharjo dkk 2002). Fuzzy AHP menutupi kelemahan yang ada pada AHP, yaitu permasalahan terhadap kriteria yang memiliki sifat subjektif lebih banyak. Fuzzy AHP pada penelitian ini bertujuan untuk mengetahui prioritas dari variabel Bauran Pemasaran 4P (price, place, promotion, product). Fuzzy AHP menggunakan TFN (Triangle Fuzzy Number) yang dikembangkan oleh (Chang, 1996). Penomoran menggunakan TFN dapat dilihat di tabel 5.

Tabel 5. Skala AHP menjadi TFN (Zeydan et al, 2011)

\begin{tabular}{lll}
\hline Skala AHP & TFN & Invers \\
\hline 1 & $(1,1,1)$ & $(1,1,1)$ \\
\hline 2 & $(1,2,3)$ & $(1 / 3,1 / 2,1)$ \\
\hline 3 & $(2,3,4)$ & $(1 / 4,1 / 3,1 / 2)$ \\
\hline 4 & $(3,4,5)$ & $(1 / 5,1 / 4,1 / 3)$ \\
\hline 5 & $(4,5,6)$ & $(1 / 6,1 / 5,1 / 4)$ \\
\hline
\end{tabular}


Pengembangan Model Kriteria Bauran Pemasaran Online Pada Tahap Creativity \& Direction Menggunakan Fuzzy Ahp (Studi Kasus: Industri Kreatif Di Indonesia)

\begin{tabular}{lll}
\hline Skala AHP & TFN & Invers \\
\hline 6 & $(5,6,7)$ & $(1 / 7,1 / 6,1 / 5)$ \\
\hline 7 & $(6,7,8)$ & $(1 / 8,1 / 7,1 / 6)$ \\
\hline 8 & $(7,8,9)$ & $(1 / 9,1 / 8,1 / 7)$ \\
\hline 9 & $(9,9,9)$ & $(1 / 9,1 / 9,1 / 9)$ \\
\hline
\end{tabular}

Pada dasarnya, Fuzzy AHP menggunakan struktur hirarki seperti pada AHP. Sebagai contoh, bauran pemasaran 4P menggunakan struktutur hirarki seperti pada Gambar 1.

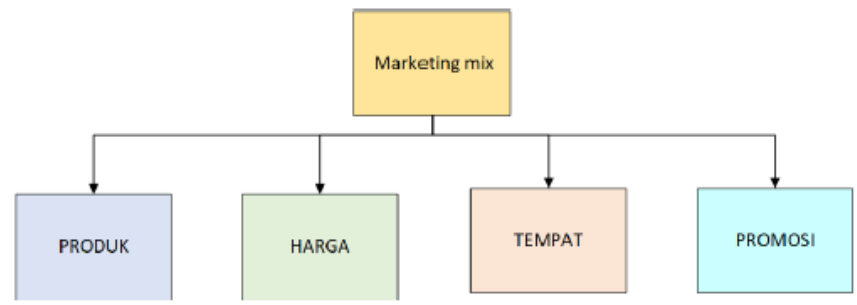

Gambar 1. Hirarki Bauran Pemasaran

\section{Hasil dan Pembahasan}

Hasil dari penelitian yang dilakukan dari metode kualitatif ada 2 yaitu, hasil rangkuman dari bauran pemasaran dan rangkuman tingkat organisasinya. Hasil didapatkan dari proses wawancara hingga teknik analisis kualitatif second cycling codes. Rangkuman penelitian dari tingkat organisasinya pada Tabel 6.

Tabel 6. Rangkuman Tahap Pertumbuhan Organisasi

\begin{tabular}{|c|c|c|c|c|}
\hline No & $\begin{array}{l}\text { Tahap Pertumbuhan } \\
\text { Organisasi }\end{array}$ & $\begin{array}{l}\text { Kicimpring } \\
\text { Cidadap }\end{array}$ & Qaireenmoez & $\begin{array}{l}\text { YME Gallery } \\
\text { \& Yemi } \\
\text { Sudibyo }\end{array}$ \\
\hline \multirow[t]{7}{*}{1} & Creativity & & & \\
\hline & Age of Organization & 2018 & 2014 & 2011 \\
\hline & Management Focus & Buat \& jual & Buat \& jual & Buat \& jual \\
\hline & Top Management Style & Individu & Individu & Individu \\
\hline & Product-Market & $\begin{array}{l}\text { Kicimpring - } \\
\text { Jual ke } \\
\text { instansi }\end{array}$ & $\begin{array}{l}\text { Kain - jual ke } \\
\text { komunitas }\end{array}$ & $\begin{array}{l}\text { Gamis - jual } \\
\text { ke } \\
\text { komunitas }\end{array}$ \\
\hline & Major Investment & Peralatan & Peralatan & Peralatan \\
\hline & $\begin{array}{l}\text { Major Source of } \\
\text { Finance }\end{array}$ & Biaya Sendiri & Biaya Sendiri & Biaya Sendiri \\
\hline \multirow[t]{4}{*}{2} & Direction & & & \\
\hline & Age of Organization & 2019 & 2017 & 2014 \\
\hline & Management Focus & $\begin{array}{l}\text { Menambah } \\
\text { pemasaran }\end{array}$ & $\begin{array}{l}\text { Penambahan } \\
\text { karyawan }\end{array}$ & $\begin{array}{l}\text { Penambahan } \\
\text { karyawan }\end{array}$ \\
\hline & Top Management Style & Directive & Individu & Directive \\
\hline
\end{tabular}




\begin{tabular}{lllll}
\hline No & $\begin{array}{l}\text { Tahap Pertumbuhan } \\
\text { Organisasi }\end{array}$ & $\begin{array}{l}\text { Kicimpring } \\
\text { Cidadap }\end{array}$ & Qaireenmoez & $\begin{array}{l}\text { YME Gallery } \\
\text { \& Yemi } \\
\text { Sudibyo }\end{array}$ \\
\hline Product-Market & $\begin{array}{l}\text { Kicimpring - } \\
\text { Jual } \text { online \& } \\
\text { jual } \text { offline }\end{array}$ & $\begin{array}{l}\text { Perluasan } \\
\text { segmentasi }\end{array}$ & Gamis \\
& Rumah & Peralatan & Toko \& \\
& produksi \& & & perlengkapan \\
& perlengkapan & & \\
\hline Major Investment & Biaya sendiri & Dana dari & Dana \\
& \& pihak & binaan & $\begin{array}{l}\text { penjualan \& } \\
\text { pihak ketiga }\end{array}$ \\
\hline Major Source of & ketiga & & \\
Finance & & &
\end{tabular}

Berdasarkan hasil pada Tabel 6, Tahap creativity UMKM diatas memiliki kesamaan terhadap kriteria Management focus dimana fokus dari masing-masing pemilik usaha pada proses produksi dan penjualan produk. Sedangkan top management style dari masing-masing usaha masih diisi oleh individu, yaitu bisnis masih dijalankan sendirisendiri. Pada product-market, market yang dituju secara terbatas kepada kelompok orang di komunitas maupun instansi. Untuk major investment dari setiap UMKM masih sama, yaitu ditujukan pada peralatan yang digunakan untuk produksi. Dan terakhir, major source of finance setiap UMKM masih menggunakan dana pribadi dalam menjalankan usahanya.

Sedangkan pada tahap direction, fokus dari manajemen untuk usaha kicimpring cidadap yaitu menambah pemasaran, sedangkan untuk Qaireenmoez \& YME Gallery melakukan penambahan karyawan. Kemudian, untuk top-management style, kicimpring cidadap \& YME Gallery merupakan Directive, yaitu pemilik usaha memiliki pegawai dan memberi arahan kepada pegawainya dalam melakukan pekerjaan, sedangkan Qaireenmoez masih individu. Perubahan juga terjadi pada major investment, yaitu kicimpring cidadap menggunakan dana investasi untuk membuat rumah produksi \& perlengkapan, YME Gallery juga menggunakan dana untuk membuka toko \& perlengkapan, sedangkan Qaireenmoez menggunakan dana untuk peralatan. Dan terakhir, untuk sumber dana setiap UMKM menggunakan sumber yang bervariasi, mulai penggunaan dana binaan \& pihak keiga. Tabel 7 menunjukkan rangkuman dari bauran pemasaran berdasarkan tahap organisasinya pada partisipan 1 .

Tabel 7. Rangkuman Bauran Pemasaran (Partisipan 1)

\begin{tabular}{lllll}
\hline No & Kriteria & Sub-kriteria & Creativity & Direction \\
\hline 1 & Produk & & & \\
\cline { 2 - 5 } & Variasi & Variasi Produk & 1 varian rasa & 4 varian rasa \\
& Produk & & (original) & (original, cokelat, \\
& & & barbeque dan buah \\
& & & naga) \\
\hline
\end{tabular}


Pengembangan Model Kriteria Bauran Pemasaran Online Pada Tahap Creativity \& Direction Menggunakan Fuzzy Ahp (Studi Kasus: Industri Kreatif Di Indonesia)

\begin{tabular}{|c|c|c|c|c|}
\hline No & Kriteria & Sub-kriteria & Creativity & Direction \\
\hline & \multirow{7}{*}{$\begin{array}{l}\text { Atribut } \\
\text { Produk }\end{array}$} & Kualitas & Fokus pada bahan & Fokus pada bahan \\
\hline & & Produk & baku berkualitas & baku berkualitas \\
\hline & & Pelayanan & $\begin{array}{l}\text { Pelayanan online } \\
\text { (facebook \& } \\
\text { whatsapp), buka } \\
\text { tidak setiap hari, } \\
\text { stok produk sedikit }\end{array}$ & $\begin{array}{l}\text { Pelayanan online \& } \\
\text { offline, buka setiap } \\
\text { hari, stok tercukupi }\end{array}$ \\
\hline & & Label & $\begin{array}{l}\text { Label merk \& } \\
\text { nomor pirt (produk } \\
\text { - industri rumah } \\
\text { tangga) }\end{array}$ & $\begin{array}{l}\text { Label merk \& } \\
\text { nomor pirt (produk } \\
\text { - industri rumah } \\
\text { tangga) }\end{array}$ \\
\hline & & Pengemasan & $\begin{array}{l}\text { Pengemasan } \\
\text { plastik bening } \\
\text { dengan stiker }\end{array}$ & $\begin{array}{l}\text { Standing pouch } \\
\text { dengan bahan dari } \\
\text { full foil }\end{array}$ \\
\hline & & Merek & Kicimpring & Kicimpring \\
\hline & & & $\begin{array}{l}\text { Cidadap, mewakili } \\
\text { nama daerah dan } \\
\text { pembeda dengan } \\
\text { produk lain }\end{array}$ & $\begin{array}{l}\text { Cidadap, mewakili } \\
\text { nama daerah dan } \\
\text { pembeda dengan } \\
\text { produk lain }\end{array}$ \\
\hline & Inovasi & Pengembangan & - & Varian rasa buah \\
\hline & Produk & Produk & & $\begin{array}{l}\text { naga, terdapat } \\
\text { campuran buah naga }\end{array}$ \\
\hline & \multirow[t]{2}{*}{$\begin{array}{l}\text { Katalog } \\
\text { Produk }\end{array}$} & Foto Produk & $\begin{array}{l}\text { Menggunakan foto } \\
\text { produk }\end{array}$ & $\begin{array}{l}\text { Menggunakan foto } \\
\text { produk }\end{array}$ \\
\hline & & $\begin{array}{l}\text { Deskripsi } \\
\text { Produk }\end{array}$ & - & $\begin{array}{l}\text { Berat kotor, nama } \\
\text { produk, variasi } \\
\text { (rasa), stok, PIRT, } \\
\text { alamat IG }\end{array}$ \\
\hline & Legalitas & Legalitas & - & Gunakan legalitas \\
\hline & Merek & Merek & & merek \\
\hline \multirow[t]{7}{*}{2} & Harga & & & \\
\hline & \multirow{6}{*}{$\begin{array}{l}\text { Metode } \\
\text { Penetapan } \\
\text { Harga }\end{array}$} & Cost Based & Menggunakan cost & Menggunakan cost \\
\hline & & Pricing & based & based \\
\hline & & & Pricing & pricing \\
\hline & & $\begin{array}{l}\text { Value Based } \\
\text { Pricing }\end{array}$ & - & - \\
\hline & & $\begin{array}{l}\text { Competition } \\
\text { based pricing }\end{array}$ & - & - \\
\hline & & $\begin{array}{l}\text { Harga } \\
\text { Psikologis }\end{array}$ & - & - \\
\hline
\end{tabular}




\begin{tabular}{|c|c|c|c|c|}
\hline No & Kriteria & Sub-kriteria & Creativity & Direction \\
\hline & & $\begin{array}{l}\text { Diskriminasi } \\
\text { Harga }\end{array}$ & $\begin{array}{l}\text { Untuk reseller, } \\
\text { pembelian } \\
\text { Minimal satu lusin }\end{array}$ & $\begin{array}{l}\text { Untuk reseller, } \\
\text { pembelian minimal } \\
\text { satu lusin. Gratis } \\
\text { ongkir di Bandung }\end{array}$ \\
\hline & $\begin{array}{l}\text { Promosi } \\
\text { Penjualan }\end{array}$ & Diskon & - & $\begin{array}{l}\text { Beli } 5 \text { kicimpring, } \\
\text { diskon } 2 \text { ribu per } \\
\text { bungkus }\end{array}$ \\
\hline & Metode & Cash & Menggunakan cash & Menggunakan cash \\
\hline & Pembayaran & Transfer Bank & $\begin{array}{l}\text { Menggunakan } \\
\text { transfer bank }\end{array}$ & $\begin{array}{l}\text { Menggunakan } \\
\text { transfer bank }\end{array}$ \\
\hline \multirow[t]{11}{*}{3} & Tempat & & & \\
\hline & Platform & Media Sosial & $\begin{array}{l}\text { Facebook \& } \\
\text { whatsapp }\end{array}$ & $\begin{array}{l}\text { Facebook, whatsapp } \\
\text { \& Instagram }\end{array}$ \\
\hline & & Lokasi & Di rumah & Di rumah \\
\hline & & Marketplace & - & - \\
\hline & $\begin{array}{l}\text { Delivery } \\
\text { Period }\end{array}$ & $\begin{array}{l}\text { Same-Day } \\
\text { Delivery }\end{array}$ & - & $\begin{array}{l}\text { Pemesanan } \\
\text { dilakukan sebelum } \\
\text { jam } 4 \text { sore }\end{array}$ \\
\hline & & $\begin{array}{l}\text { Next-Day } \\
\text { Delivery }\end{array}$ & - & $\begin{array}{l}\text { Pemesanan } \\
\text { dilakukan setelah } \\
\text { jam } 4 \text { sore }\end{array}$ \\
\hline & $\begin{array}{l}\text { Saluran } \\
\text { Distribusi }\end{array}$ & $\begin{array}{l}\text { Distribusi } \\
\text { Langsung }\end{array}$ & $\begin{array}{l}\text { Langsung ke } \\
\text { pembeli }\end{array}$ & $\begin{array}{l}\text { Langsung ke } \\
\text { pembeli }\end{array}$ \\
\hline & & $\begin{array}{l}\text { Distribusi } \\
\text { Tidak } \\
\text { Langsung }\end{array}$ & Melalui reseller & Melalui reseller \\
\hline & $\begin{array}{l}\text { Jasa } \\
\text { Pengiriman }\end{array}$ & Pos Indonesia & - & $\begin{array}{l}\text { Menggunakan jasa } \\
\text { ini }\end{array}$ \\
\hline & & JNE & - & - \\
\hline & & Gosend & - & $\begin{array}{l}\text { Menggunakan jasa } \\
\text { ini }\end{array}$ \\
\hline \multirow[t]{6}{*}{4} & Promosi & & & \\
\hline & Pemasaran & Facebook & Gunakan facebook & Gunakan facebook \\
\hline & Media & Whatsapp & Gunakan whatsapp & Gunakan whatsapp \\
\hline & Sosial & Instagram & - & Gunakan Instagram \\
\hline & & $\begin{array}{l}\text { Blackberry } \\
\text { Messenger }\end{array}$ & - & - \\
\hline & $\begin{array}{l}\text { Strategi } \\
\text { Promosi }\end{array}$ & Pameran & - & $\begin{array}{l}\text { Di Sangkuriang, } \\
\text { Papandayan \& } \\
\text { UMKM awards }\end{array}$ \\
\hline
\end{tabular}


Pengembangan Model Kriteria Bauran Pemasaran Online Pada Tahap Creativity \& Direction Menggunakan Fuzzy Ahp (Studi Kasus: Industri Kreatif Di Indonesia)

\begin{tabular}{lllll}
\hline No & Kriteria & Sub-kriteria & Creativity & Direction \\
\hline & & Content & - & - \\
& Marketing & & \\
\cline { 2 - 4 } & Video & - & - \\
& Marketing & & Menggunakan \\
& Personal & Menggunakan & personal selling \\
& Selling & personal selling & Belum lama ini di \\
& Influencer & Celebrity & - & ardan radio \\
Marketing & Endorser & & - \\
\cline { 2 - 4 } & Typical- & - & \\
& Person & & Sekitar 15\% dari \\
& Endorser & & pengeluaran \\
\hline Rencana & Jadwal & - & \\
Promosi & Promosi & & \\
\cline { 2 - 4 } & Biaya Promosi & - & \\
& & & \\
& & & \\
& &
\end{tabular}

Pada penelitian ini, setiap kriteria Bauran Pemasaran menggunakan skala ukur yang bertujuan mengetahui posisi sebuah UMKM. Penelitian dilakukan pada 6 partisipan, 3 partisipan berada tahap creativity dan tahap direction dan 3 partisipan hanya berada tahap creativity. Kesimpulan yang didapat, UMKM pada tahap direction memiliki skor lebih tinggi disebabkan UMKM pada tahap tersebut telah menggunakan pemasaran yang terdapat kriteria Bauran Pemasaran tersebut. Hasil metode kualitatif dapat dilihat pada Tabel 8.

Tabel 8. Hasil metode Kualitatif

\begin{tabular}{llllllll}
\hline No & Partisipan & $\begin{array}{l}\text { Tahap } \\
\text { pertumbuhan } \\
\text { organisasi }\end{array}$ & Produk & Harga & Tempat & Promosi & Total \\
\hline 1 & $\begin{array}{l}\text { Kicimpring } \\
\text { cidadap } \\
\text { (Partisipan }\end{array}$ & Creativity & 7 & 4 & 4 & 3 & 18 \\
\cline { 2 - 8 } & Direction & 12 & 5 & 8 & 7 & 30 \\
\hline 2 & $\begin{array}{l}\text { Qaireenmoez } \\
\text { (Partisipan }\end{array}$ & Creativity & 8 & 5 & 4 & 5 & 22 \\
\cline { 2 - 8 } & 2) & 11 & 7 & 8 & 7 & 32 \\
\hline 3 & $\begin{array}{l}\text { YME } \\
\text { Gallection }\end{array}$ & Creativity & 8 & 5 & 3 & 4 & 20 \\
\cline { 2 - 8 } & Direction & 11 & 7 & 5 & 6 & 27 \\
& 3artisipan & & & & & & \\
\hline
\end{tabular}


Hasrini Sari, Made Andriani, Irfan Rusydi Triyanto

\begin{tabular}{|c|c|c|c|c|c|c|c|}
\hline 4 & $\begin{array}{l}\text { Sharena } \\
\text { handicraft } \\
\text { (Partisipan } \\
\text { 4) }\end{array}$ & Creativity & 10 & 5 & 6 & 4 & 23 \\
\hline 5 & $\begin{array}{l}\text { Mama masak } \\
\text { (Partisipan } \\
\text { 5) }\end{array}$ & Creativity & 8 & 5 & 8 & 5 & 25 \\
\hline 6 & $\begin{array}{l}\text { Ranemo } \\
\text { (Partisipan } \\
\text { 6) }\end{array}$ & Creativity & 9 & 6 & 6 & 5 & 24 \\
\hline
\end{tabular}

Hasil Metode kuantitatif pada penelitian ini menggunakan Fuzzy AHP. Struktur hirarki disusun berdasarkan hasil dari rangkuman bauran pemasaran penelitian kualitatif. Pada perhitungan Fuzzy AHP, hanya bauran pemasaran yang diteliti. Hirarki dimensi Bauran Pemasaran dapat dilihat pada Gambar 2, Gambar 3, Gambar 4 dan Gambar 5.

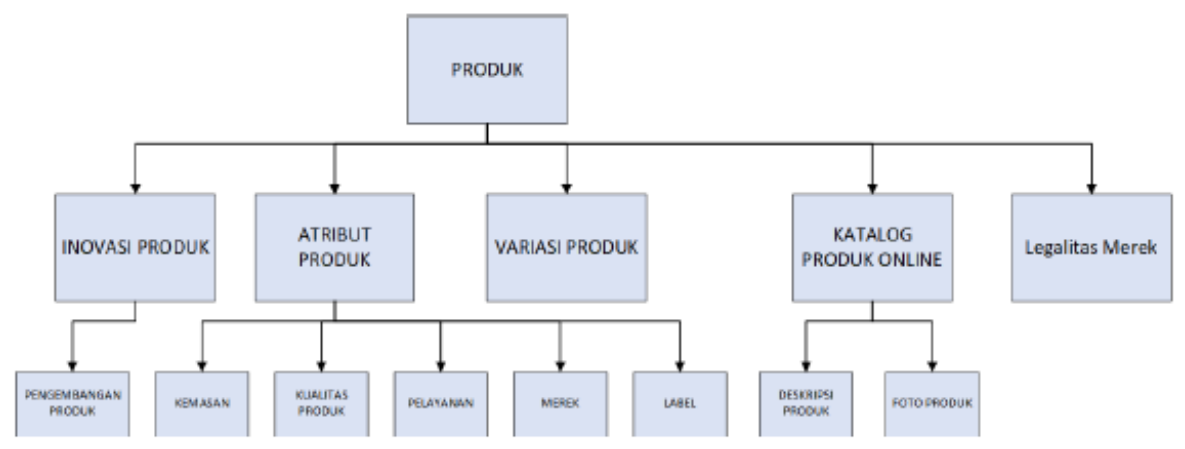

Gambar 2. Hirarki Dimensi Produk

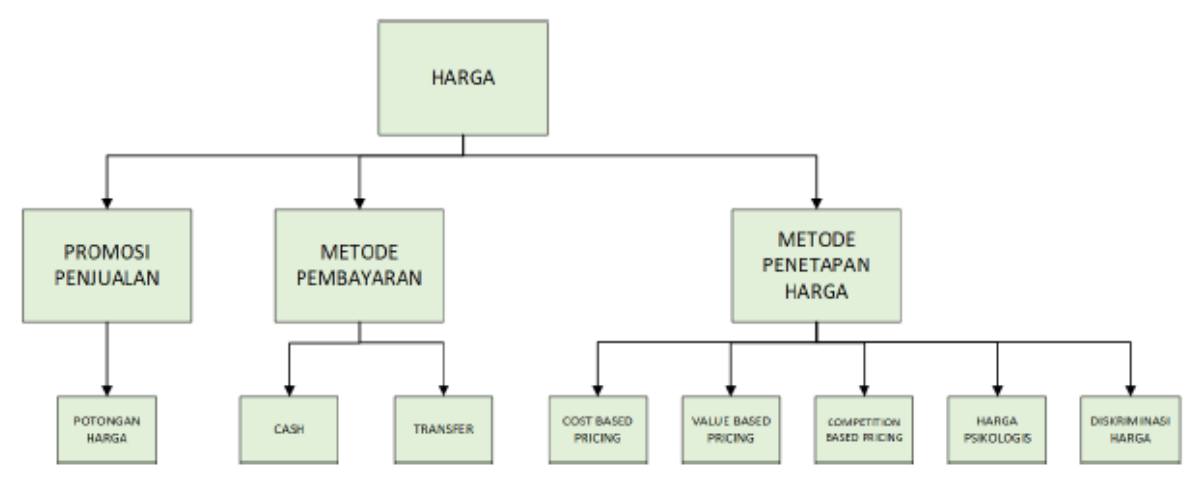

Gambar 3. Hirarki Dimensi Harga 
Pengembangan Model Kriteria Bauran Pemasaran Online Pada Tahap Creativity \& Direction Menggunakan Fuzzy Ahp (Studi Kasus: Industri Kreatif Di Indonesia)

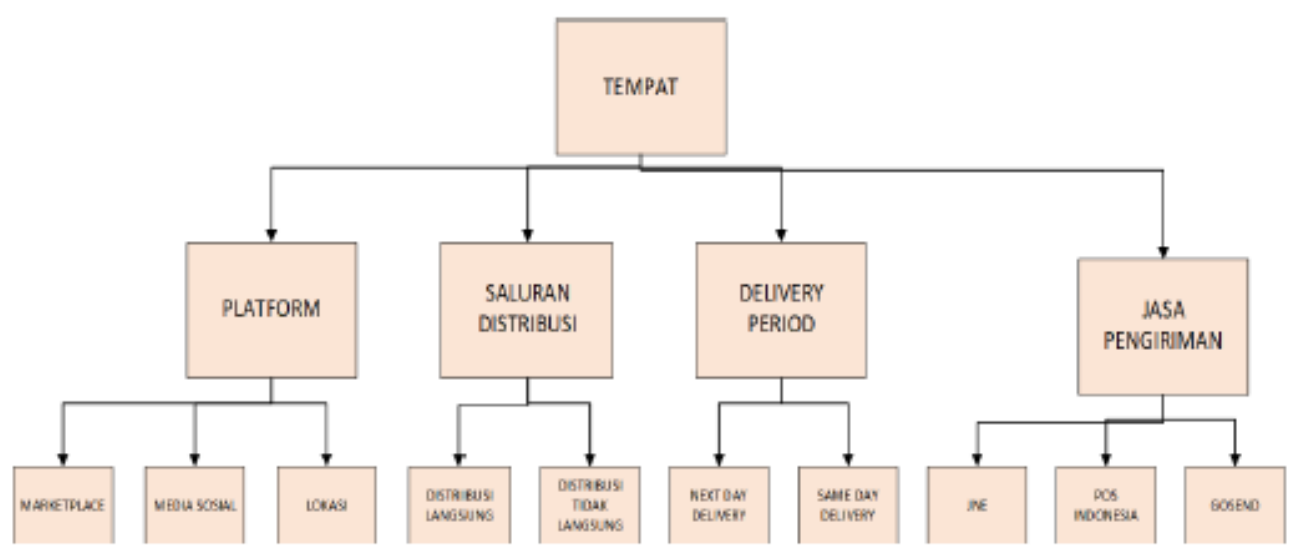

Gambar 4. Hirarki Dimensi Tempat

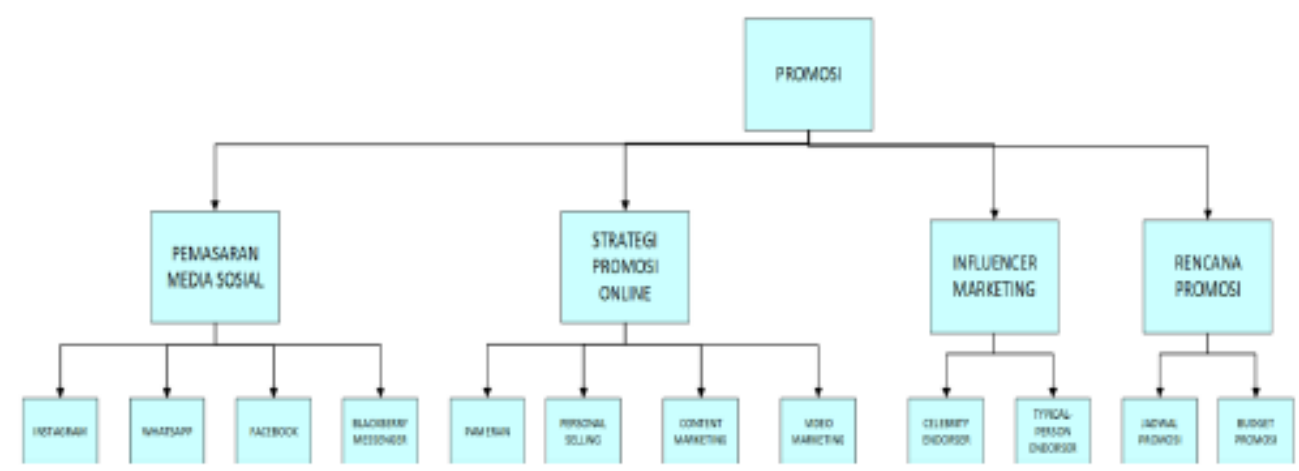

Gambar 5. Hirarki Dimensi Promosi

Dari hasil Gambar diatas, yang selanjutnya dilakukan yaitu melakukan peringkat terhadap bauran pemasaran. Tabel 9 menunjukkan peringkat kriteria bauran pemasaran pada tahap creativity.

Tabel 9. Peringkat Kriteria Bauran Pemasaran Tahap Creativity

\begin{tabular}{clllr}
\hline Peringkat & Kriteria & Dimensi & $\begin{array}{l}\text { Bobot } \\
(\boldsymbol{\%})\end{array}$ & $\begin{array}{l}\text { Bobot } \\
\text { Kumulatif (\%) }\end{array}$ \\
\hline 1. & Variasi Produk & Produk & $15,60 \%$ & $15,60 \%$ \\
\hline 2. & Inovasi Produk & Produk & $8,80 \%$ & $24,40 \%$ \\
\hline 3. & Foto Produk & Produk & $5,50 \%$ & $29,90 \%$ \\
\hline 4. & Legalitas Merek & Produk & $5,30 \%$ & $35,20 \%$ \\
\hline 5. & Promosi Penjualan & Harga & $5,20 \%$ & $40,40 \%$ \\
\hline 6. & Cash & Harga & $3,96 \%$ & $44,35 \%$ \\
\hline 7. & Kualitas Produk & Produk & $3,40 \%$ & $47,75 \%$ \\
\hline 8. & Deskripsi Produk & Produk & $3,20 \%$ & $50,95 \%$ \\
\hline 9. & Whatsapp & Promosi & $2,86 \%$ & $53,81 \%$ \\
\hline 10. & Value Based Pricing & Harga & $2,79 \%$ & $56,60 \%$ \\
\hline 11. & Cost Based Pricing & Harga & $2,68 \%$ & $59,28 \%$ \\
\hline 12. & Transfer Bank & Harga & $2,30 \%$ & $61,58 \%$ \\
\hline
\end{tabular}




\begin{tabular}{|c|c|c|c|c|}
\hline Peringkat & Kriteria & Dimensi & $\begin{array}{l}\text { Bobot } \\
(\%)\end{array}$ & $\begin{array}{l}\text { Bobot } \\
\text { Kumulatif (\%) }\end{array}$ \\
\hline 13. & Pelayanan & Produk & $2,20 \%$ & $63,78 \%$ \\
\hline 14. & Pameran & Promosi & $2,18 \%$ & $65,96 \%$ \\
\hline 15. & Jadwal Promosi & Promosi & $2,03 \%$ & $67,99 \%$ \\
\hline 16. & Next-Day Delivery & Tempat & $2,01 \%$ & $70,01 \%$ \\
\hline 17. & Diskriminasi Harga & Harga & $1,89 \%$ & $71,89 \%$ \\
\hline 18. & $\begin{array}{l}\text { Competition Based } \\
\text { Pricing }\end{array}$ & Harga & $1,80 \%$ & $73,69 \%$ \\
\hline 19. & Lokasi & Tempat & $1,70 \%$ & $75,39 \%$ \\
\hline 20. & Media Sosial & Tempat & $1,66 \%$ & $77,05 \%$ \\
\hline 21. & Same-Day Delivery & Tempat & $1,66 \%$ & $78,71 \%$ \\
\hline 22. & Pengemasan & Produk & $1,60 \%$ & $80,31 \%$ \\
\hline 23. & Personal Selling & Promosi & $1,56 \%$ & $81,87 \%$ \\
\hline 24. & Celebrity Endorser & Promosi & $1,51 \%$ & $83,38 \%$ \\
\hline 25. & Harga Psikologis & Harga & $1,42 \%$ & $84,80 \%$ \\
\hline 26. & Distribusi Langsung & Tempat & $1,42 \%$ & $86,22 \%$ \\
\hline 27. & Marketplace & Tempat & $1,40 \%$ & $87,62 \%$ \\
\hline 28. & $\begin{array}{l}\text { Typical Person } \\
\text { Endorser }\end{array}$ & Promosi & $1,35 \%$ & $88,97 \%$ \\
\hline 29. & Label & Produk & $1,30 \%$ & $90,27 \%$ \\
\hline 30. & Instagram & Promosi & $1,24 \%$ & $91,50 \%$ \\
\hline 31. & Merek & Produk & $1,20 \%$ & $92,70 \%$ \\
\hline 32. & Content Marketing & Promosi & $1,16 \%$ & $93,86 \%$ \\
\hline 33. & Facebook & Promosi & $1,11 \%$ & $94,97 \%$ \\
\hline 34. & Biaya Promosi & Promosi & $1,06 \%$ & $96,03 \%$ \\
\hline 35. & Video Marketing & Tempat & $0,97 \%$ & $97,00 \%$ \\
\hline 36. & Gosend & Tempat & $0,87 \%$ & $97,87 \%$ \\
\hline 37. & $\begin{array}{l}\text { Distribusi Tidak } \\
\text { Langsung }\end{array}$ & Tempat & $0,67 \%$ & $98,54 \%$ \\
\hline 38. & JNE & Tempat & $0,61 \%$ & $99,15 \%$ \\
\hline 39. & Pos Indonesia & Tempat & $0,45 \%$ & $99,60 \%$ \\
\hline 40. & Blackberry Messenger & Promosi & $0,40 \%$ & $100,0 \%$ \\
\hline
\end{tabular}

Selanjutnya pada Tabel 10 menunjukkan peringkat kriteria Bauran Pemasaran pada tahap Direction.

Tabel 10. Peringkat Kriteria bauran Pemasaran Tahap Direction

\begin{tabular}{clllll}
\hline Peringkat & Kriteria & Dimensi & $\begin{array}{l}\text { Bobot } \\
(\boldsymbol{\%})\end{array}$ & $\begin{array}{l}\text { Bobot } \\
(\boldsymbol{\%})\end{array}$ & kumulatif \\
\hline 1. & Inovasi Produk & Produk & $11,40 \%$ & $11,40 \%$ & \\
\hline 2. & Foto Produk & Produk & $8,20 \%$ & $19,60 \%$ & \\
\hline
\end{tabular}


Pengembangan Model Kriteria Bauran Pemasaran Online Pada Tahap Creativity \& Direction Menggunakan Fuzzy Ahp (Studi Kasus: Industri Kreatif Di Indonesia)

\begin{tabular}{|c|c|c|c|c|}
\hline Peringkat & Kriteria & Dimensi & $\begin{array}{l}\text { Bobot } \\
(\%)\end{array}$ & $\begin{array}{l}\text { Bobot kumulatif } \\
(\%)\end{array}$ \\
\hline 3. & Legalitas Merek & Produk & $6,80 \%$ & $26,40 \%$ \\
\hline 4. & Variasi Produk & Produk & $5,00 \%$ & $31,40 \%$ \\
\hline 5. & Distribusi Langsung & Tempat & $4,21 \%$ & $35,61 \%$ \\
\hline 6. & Promosi Penjualan & Harga & $3,95 \%$ & $39,55 \%$ \\
\hline 7. & Biaya Promosi & Promosi & $3,30 \%$ & $42,85 \%$ \\
\hline 8. & Celebrity Endorser & Promosi & $3,30 \%$ & $46,15 \%$ \\
\hline 9. & Kualitas Produk & Produk & $3,00 \%$ & $49,15 \%$ \\
\hline 10. & Pelayanan & Produk & $3,00 \%$ & $52,15 \%$ \\
\hline 11. & Cost Based Pricing & Harga & $2,90 \%$ & $55,05 \%$ \\
\hline 12. & Deskripsi Produk & Produk & $2,80 \%$ & $57,85 \%$ \\
\hline 13. & $\begin{array}{l}\text { Competition Based } \\
\text { Pricing }\end{array}$ & Harga & $2,64 \%$ & $60,50 \%$ \\
\hline 14. & Value Based Pricing & Harga & $2,46 \%$ & $62,96 \%$ \\
\hline 15. & $\begin{array}{l}\text { Typical Person } \\
\text { Endorser }\end{array}$ & Promosi & $2,41 \%$ & $65,37 \%$ \\
\hline 16. & Jadwal Promosi & Promosi & $2,30 \%$ & $67,67 \%$ \\
\hline 17. & Lokasi & Tempat & $2,28 \%$ & $69,95 \%$ \\
\hline 18. & Content Marketing & Promosi & $2,13 \%$ & $72,08 \%$ \\
\hline 19. & Diskriminasi Harga & Harga & $2,06 \%$ & $74,14 \%$ \\
\hline 20. & Next Day Delivery & Tempat & $2,00 \%$ & $76,13 \%$ \\
\hline 21. & Marketplace & Tempat & $1,92 \%$ & $78,06 \%$ \\
\hline 22. & Media Sosial & Tempat & $1,90 \%$ & $79,95 \%$ \\
\hline 23. & Harga Psikologis & Harga & $1,73 \%$ & $81,69 \%$ \\
\hline 24. & $\begin{array}{l}\text { Distribusi Tidak } \\
\text { Langsung }\end{array}$ & Tempat & $1,70 \%$ & $83,39 \%$ \\
\hline 25. & Instagram & Promosi & $1,48 \%$ & $84,86 \%$ \\
\hline 26. & Whatsapp & Promosi & $1,47 \%$ & $86,33 \%$ \\
\hline 27. & Cash & Harga & $1,44 \%$ & $87,77 \%$ \\
\hline 28. & Transfer Bank & Harga & $1,44 \%$ & $89,21 \%$ \\
\hline 29. & Pameran & Promosi & $1,10 \%$ & $90,31 \%$ \\
\hline 30. & Label & Produk & $1,15 \%$ & $91,45 \%$ \\
\hline 31. & Same-Day Delivery & Tempat & $1,10 \%$ & $92,55 \%$ \\
\hline 32. & Merek & Produk & $1,00 \%$ & $93,55 \%$ \\
\hline 33. & Personal Selling & Promosi & $1,00 \%$ & $94,55 \%$ \\
\hline 34. & Pengemasan & Produk & $0,90 \%$ & $95,45 \%$ \\
\hline 35. & Gosend & Tempat & $0,88 \%$ & $96,33 \%$ \\
\hline 36. & Facebook & Promosi & $0,83 \%$ & $97,16 \%$ \\
\hline 37. & Pos Indonesia & Tempat & $0,82 \%$ & $97,99 \%$ \\
\hline
\end{tabular}




\begin{tabular}{cllll}
\hline Peringkat & Kriteria & Dimensi & $\begin{array}{l}\text { Bobot } \\
(\boldsymbol{\%})\end{array}$ & $\begin{array}{l}\text { Bobot } \\
\mathbf{( \% )}\end{array}$ \\
\hline 38. & $\begin{array}{l}\text { Blackberry } \\
\text { Messenger }\end{array}$ & Promosi & & \\
& & $0,80 \%$ & $98,79 \%$ \\
\hline 39. & JNE & Tempat & $0,77 \%$ & $99,56 \%$ \\
\hline 40. & Video Marketing & Promosi & $0,58 \%$ & $100 \%$ \\
\hline
\end{tabular}

Hasil perbandingan bauran pemasaran online antara tahap creativity dapat digunakan sebagai informasi bagi UMKM. Dengan menggunakan perhitungan bobot kumulatif kinerja bauran pemasaran online UMKM tersebut dengan skor maksimal adalah 1 ketika UMKM menggunakan keseluruhan kriteria bauran pemasaran. Tabel 11 menunjukkan evaluasi bauran pemasaran online yang dilakukan oleh Kicimpring Cidadap (partisipan 1).

Tabel 11. Evaluasi Bauran Pemasaran Online (Partisipan 1)

\begin{tabular}{|c|c|c|c|c|c|c|c|}
\hline Kriteria & $\begin{array}{l}\text { Priorit } \\
y \\
\text { Weigh } \\
t\end{array}$ & Nilai & Skor & Kriteria & $\begin{array}{l}\text { Priori } \\
\text { ty } \\
\text { Weig } \\
\text { ht }\end{array}$ & Nilai & Skor \\
\hline Inovasi & 11,40 & & 0,11 & Marketplac & 1,92 & 0 & 0 \\
\hline Produk & $\%$ & 1 & 4 & $e$ & $\%$ & & \\
\hline \multirow[t]{2}{*}{ Foto Produk } & \multirow{2}{*}{$8,20 \%$} & & 0,08 & Media & 1,90 & & 0,01 \\
\hline & & 1 & 2 & Sosial & $\%$ & 1 & 9 \\
\hline Legalitas & \multirow{2}{*}{$6,80 \%$} & & 0,06 & Harga & 1,73 & & \\
\hline Merek & & 1 & 8 & Psikologis & $\%$ & 0 & 0 \\
\hline \multirow{3}{*}{$\begin{array}{l}\text { Variasi } \\
\text { Produk }\end{array}$} & \multirow{3}{*}{$5,00 \%$} & & & Distribusi & \multirow{3}{*}{$\begin{array}{l}1,70 \\
\%\end{array}$} & & \\
\hline & & & & Tidak & & & 0,01 \\
\hline & & 1 & 0,05 & Langsung & & 1 & 7 \\
\hline Distribusi & \multirow{2}{*}{$4,21 \%$} & & 0,04 & Instagram & 1,48 & & 0,01 \\
\hline Langsung & & 1 & 21 & & $\%$ & 1 & 48 \\
\hline Promosi & \multirow{2}{*}{$3,95 \%$} & & 0,03 & Whatsapp & 1,47 & & 0,01 \\
\hline Penjualan & & 1 & 95 & & $\%$ & 1 & 47 \\
\hline \multirow[t]{2}{*}{ Pelayanan } & \multirow{2}{*}{$3,00 \%$} & & & Cash & 1,44 & & 0,01 \\
\hline & & 1 & 0,09 & & $\%$ & 1 & 44 \\
\hline Kualitas & \multirow{2}{*}{$3,00 \%$} & & & Transfer & 1,44 & & 0,01 \\
\hline Produk & & 1 & 0,03 & Bank & $\%$ & 1 & 44 \\
\hline Biaya & \multirow{2}{*}{$3,35 \%$} & & 0,03 & Label & 1,15 & & 0,01 \\
\hline Promosi & & 1 & 35 & & $\%$ & 1 & 15 \\
\hline Deskripsi & \multirow{2}{*}{$2,80 \%$} & & 0,02 & Merek & 1,00 & & \\
\hline Produk & & 1 & 8 & & $\%$ & 1 & 0,01 \\
\hline Celebrity & \multirow{2}{*}{$3,10 \%$} & & 0,03 & Same-Day & 1,10 & & 0,01 \\
\hline Endorser & & 1 & 1 & Delivery & $\%$ & 1 & 1 \\
\hline
\end{tabular}


Pengembangan Model Kriteria Bauran Pemasaran Online Pada Tahap Creativity \& Direction Menggunakan Fuzzy Ahp (Studi Kasus: Industri Kreatif Di Indonesia)

\begin{tabular}{|c|c|c|c|c|c|c|c|}
\hline Kriteria & $\begin{array}{l}\text { Priorit } \\
y \\
\text { Weigh } \\
t\end{array}$ & Nilai & Skor & Kriteria & $\begin{array}{l}\text { Priori } \\
\text { ty } \\
\text { Weig } \\
\text { ht }\end{array}$ & Nilai & Skor \\
\hline $\begin{array}{l}\text { Cost Based } \\
\text { Pricing }\end{array}$ & $2,90 \%$ & 1 & $\begin{array}{l}0,02 \\
9\end{array}$ & Pameran & $\begin{array}{l}1,07 \\
\%\end{array}$ & 1 & $\begin{array}{l}0,01 \\
07\end{array}$ \\
\hline $\begin{array}{l}\text { Competition } \\
\text { Based } \\
\text { Pricing }\end{array}$ & $2,64 \%$ & 0 & 0 & $\begin{array}{l}\text { Pengemasa } \\
\mathrm{n}\end{array}$ & $\begin{array}{l}0,90 \\
\%\end{array}$ & 1 & $\begin{array}{l}0,00 \\
9\end{array}$ \\
\hline $\begin{array}{l}\text { Value Based } \\
\text { Pricing }\end{array}$ & $2,46 \%$ & 0 & 0 & $\begin{array}{l}\text { Personal } \\
\text { Selling }\end{array}$ & $\begin{array}{l}0,99 \\
\%\end{array}$ & 1 & $\begin{array}{l}0,00 \\
99\end{array}$ \\
\hline $\begin{array}{l}\text { Typical- } \\
\text { Person } \\
\text { Endorser }\end{array}$ & $2,41 \%$ & 0 & 0 & Gosend & $\begin{array}{l}0,88 \\
\%\end{array}$ & 1 & $\begin{array}{l}0,00 \\
88\end{array}$ \\
\hline $\begin{array}{l}\text { Jadwal } \\
\text { Promosi }\end{array}$ & $2,30 \%$ & 0 & 0 & Facebook & $\begin{array}{l}0,83 \\
\%\end{array}$ & 1 & $\begin{array}{l}0,00 \\
83\end{array}$ \\
\hline Lokasi & $2,28 \%$ & 1 & $\begin{array}{l}0,02 \\
28\end{array}$ & $\begin{array}{l}\text { Pos } \\
\text { Indonesia }\end{array}$ & $\begin{array}{l}0,82 \\
\%\end{array}$ & 1 & $\begin{array}{l}0,00 \\
82\end{array}$ \\
\hline $\begin{array}{l}\text { Content } \\
\text { Marketing }\end{array}$ & $2,13 \%$ & 0 & 0 & $\begin{array}{l}\text { Blackberry } \\
\text { Messenger }\end{array}$ & $\begin{array}{l}0,80 \\
\%\end{array}$ & 0 & 0 \\
\hline $\begin{array}{l}\text { Diskriminasi } \\
\text { Harga }\end{array}$ & $2,06 \%$ & 1 & $\begin{array}{l}0,02 \\
06\end{array}$ & JNE & $\begin{array}{l}0,77 \\
\%\end{array}$ & 0 & 0 \\
\hline $\begin{array}{l}\text { Next-Day } \\
\text { Delivery }\end{array}$ & $2,00 \%$ & 1 & 0,02 & $\begin{array}{l}\text { Video } \\
\text { Marketing }\end{array}$ & $\begin{array}{l}0,58 \\
\%\end{array}$ & 0 & 0 \\
\hline & & & & Total & & 32 & $\begin{array}{l}0,82 \\
2\end{array}$ \\
\hline
\end{tabular}

Pengolahan data pada Tabel 10 menunjukkan bahwa kicimpring cidadap memiliki skor evaluasi sebesar 0,822. Berikut adalah hasil pengolahan data kuesioner evaluasi UMKM dari 6 sampel partisipan lainnya di Tabel 11.

Tabel 11. Hasil Evaluasi Bauran Pemasaran Online UMKM

\begin{tabular}{lllllll}
\hline $\begin{array}{l}\text { Tahap } \\
\text { Pertumbuha } \\
\text { n Organisasi }\end{array}$ & Direction & & & Creativity & & \\
\hline Nama Bisnis & Kicimprin & Qaireenmoe & YME & Sharena & Mama & Ranem \\
& g & $\mathrm{z}$ & Galler & Handicraf & Masa & o \\
& Cidadap & & $\mathrm{y}$ & $\mathrm{t}$ & $\mathrm{k}$ & \\
\hline Skor Evaluasi & 0,822 & 0,851 & 0,769 & 0,735 & 0,666 & 0,769 \\
\hline Nilai rata-rata & 0,814 & & & 0,723 & & \\
\hline
\end{tabular}


Hasil tabel 11 menunjukkan perbedaan sebesar 0,09. Hasil ini menunjukkan terdapat perbedaan antara UMKM yang ada di tahap creativity dan direction. Hasil yang lebih besar dari UMKM tahap direction disebabkan UMKM pada tahap tersebut menggunakan lebih banyak kriteria Bauran Pemasaran dibandingkan UMKM tahap creativity.

\section{Kesimpulan}

Penelitian ini menggunakan 6 partisipan UMKM, dimana ada 3 partisipan yang berada di tahap creativity dan 3 partisipan berada di tahap direction. Penelitian ini bertujuan untuk melihat perbandingan bauran pemasaran di tahap creativity dan di tahap direction. Pada tahap Creativity, Bauran pemasaran yang dapat dilakukan, antara lain:

1. Kualitas produk dari UMKM makanan \& kerajinan berfokus pada bahan baku, UMKM fashion berfokus pada jahitan.

2. Label dari UMKM kerajinan \& fashion hanya label merek, UMKM makanan ditambahkan No-pirt.

3. Pengemasan dari UMKM makanan berupa botol \& plastik

4. Pengembangan produk dilakukan oleh UMKM fashion \& UMKM kerajinan

5. Harga psikologis perlu dilakukan UMKM, terutama industri fashion

6. Celebrity endorser UMKM makanan menggunakan selebgram, UMKM fashion menggunakan model professional

Bauran Pemasaran yang dapat dilakukan ketika UMKM berada di tahap direction antara lain:

1. Pengembangan produk perlu dilakukan UMKM makanan dalam memberi keunggulan bersaing dalam berjualan.

2. Seluruh UMKM perlu memperhatikan aspek pengemasan, terutama UMKM makanan dengan menggunakan stand pouch

3. Metode penerapan harga terutama value based pricing \& competition based pricing dilakukan oleh UMKM fashion.

4. Celebrity endorser UMKM fashion menggunakan model profesional, UMKM makanan menggunakan penyiar radio 
Pengembangan Model Kriteria Bauran Pemasaran Online Pada Tahap Creativity \& Direction Menggunakan Fuzzy Ahp (Studi Kasus: Industri Kreatif Di Indonesia)

\section{Bibliografi}

Albuquerque, Alexandre Farias, Escrivão Filho, Edmundo, Nagano, Marcelo Seido, \& Junior, Luiz Adalberto Philippsen. (2016). A change in the importance of mortality factors throughout the life cycle stages of small businesses. Journal of Global Entrepreneurship Research, 6(1), 1-18.

Chaffey, Dave, Ellis-Chadwick, Fiona, Mayer, Richard, \& Johnston, Kevin. (2009). Internet marketing: strategy, implementation and practice. Pearson Education.

Chang, Da Yong. (1996). Applications of the extent analysis method on fuzzy AHP. European Journal of Operational Research, 95(3), 649-655. https://doi.org/10.1016/0377-2217(95)00300-2

Gilmore, Audrey, Carson, David, \& Grant, Ken. (2001). SME marketing in practice. Marketing Intelligence \& Planning. https://doi.org/10.1108/02634500110363583

Greiner, Larry E. (1972). Evolution and revolution. Organization Growth." Hanurcf Business Ke.

Indonesia, Republik. (2008). Undang-Undang No. 20 Tahun 2008 tentang Usaha Mikro, Kecil, dan Menengah. Jakarta: Sekretariat Negara.

Kotler, Philip. (2012). Marketing management/Philip Kotler, Kevin Lane Keller. Pearson Education International.

Kotler, Philip, \& Keller, Kevin Lane. (2016). A framework for marketing management. Pearson Boston, MA.

Miles, Matthew B., Huberman, A. Michael, \& Saldana, Johnny. (2014). Qualitative data analysis: A methods sourcebook.

Moleong, Lexy J. (2012). Metodologi Penelitian Kualitatif, Bandung. Pariwisata Pedesaan Sebagai Alternatif Pembangunan Berkelanjutan (Laporan Penelitian Hibah Bersaing Perguruan Tinggi) Yogyakarta.

Nezamabad, Mehdi Naimi. (2011). The impact and benefits of Internet on marketing mix. Australian Journal of Basic and Applied Sciences, 5(9), 1784-1789.

Nuriyanti, Widya. (2019). Peran Media Sosial dalam Perkembangan Industri Kreatif. Sosio E-Kons, 11(2), 101-107. http://dx.doi.org/10.30998/sosioekons.v11i2.3102

Richter, Alexander, \& Koch, Michael. (2007). Social software-status quo und Zukunft. Fak. für Informatik, Univ. der Bundeswehr München Munich.

Schenck, Barbara Findlay. (2012). Small business marketing kit for dummies. John Wiley \& Sons. 
Hasrini Sari, Made Andriani, Irfan Rusydi Triyanto

Sugiyono. (2012). Metode Penelitian Kuantitatif. 46-57.

Sugiyono, P. D. (2017). Metode Penelitian Bisnis: Pendekatan Kuantitatif, Kualitatif, Kombinasi, dan R\&D. Penerbit CV. Alfabeta: Bandung.

Widyastuti, Dominica A. (2020). Panduan dalam Penerapan Pemasaran Digital Melalui Media Sosial pada Usaha Mikro. 